4. Tulchinsky, G., Shekova, E. (2009). Management in the field of culture. Tutorial [Menedzhment $v$ sfere kulturyi. Uchebnoe posobie]. Moscow, The Lan/The Planet of Music. 272 p.

5. Shcherbyna $V$. Dialogue of cultures in the conditions of modern multidimensional society. Concept of culture: theoretical and methodological and applied aspects [Dialoh kul'tur $v$ umovakh suchasnoho bahatovymirnoho suspil'stva. Kontsept kul'tury: teoretykometodolohichni ta prykladni aspekty]. Collection of scientific works. Issue 2. Institute of Cultural Studies of the National Academy of Sciences of Ukraine. K., 2011. P. 126-162.

УДК 78.071.1(477)

ORCID: 0000-0003-2796-6676

Віктор Бондарчук,

кандидат мистецтввознавства, доцент Національної музичної академії Украӥни ім. П. І. Чайковського, вул. Архітектора Городецького, 1-3/11, Київ, 02000, Україна

Viktor Bondarchuk,

Ph.D. in Arts, Associate Professor, Ukrainian National Tchaikovsky academy of music, 1-3/11 Architect Gorodetsky St., Kyiv 02000, Ukraine

\title{
Д. М. ГНАТЮК І ВІТЧИЗНЯНЕ ОПЕРНЕ ВИКОНАВСТВО (СТАНОВЛЕННЯ ОСОБИСТОСТІ)
}

Тема висвітлює період, який став знаменним у творчій біографії Д. Гнатюка - період його навчання у Київській консерваторії. У дослідженні сфокусовано увагу на біографічних аспектах митця, які, будучи закріпленими в контекст вітчизняної соціокультурної динаміки середини XX століття дають можливість осягнути вектори не тільки музичної освіти, а й прослідкувати рух загальних культурно-мистецьких тенденцій часу.

Ключові слова: музична освіта, Оперна студія, сольний спів, творче амплуа оперного виконавця, концепція сценічного втілення ролі, драматургічне завдання.

D. M. Gnatyuk and the domestic opera performance (formation of personality). The theme highlights the period that became significant in the creative biography of D. Gnatyuk - the period of his studies at the Kyiv Conservatory. The study focuses on the biographical aspects of the artist, which, being entrenched in the context of the national socio-cultural dynamics of the middle of the twentieth century, provide an opportunity to comprehend the vectors of not only musical education, but also to follow the movement of general cultural and artistic tendencies of time.

Key words: musical education, opera studio, solo singing, creative role of opera performer, conception of stage performance of the role, dramatic task. 


\section{Д. М. Гнатюк и отечественное оперное исполнительство} (становление личности). Тема освещает период, ставший знаменательным в творческой биографии Д. Гнатюка - период его обучения в Киевской консерватории. В исследовании сфокусировано внимание на биографических аспектах художника, которые, будучи закрепленными в контекст отечественной социокультурной динамики середины XX века дают возможность понять векторы не только музыкального образования, но и проследить движение общих культурных тенденций времени.

Ключевые слова: образование, Оперная студия, сольное пение, творческое амплуа оперного исполнителя, концепция сценического воплощения роли, драматургическое задачи.

У координатах складного i динамічного соціокультурного дискурсу, сформованого проблемою даного дослідження, чітко прослідковується його основа, сутність - творча особистість як осереддя, магістральний вектор, що ініціює і стимулює комунікативні перетворення в культурі держави, нації, відповідному локальному середовищі. Генетично закорінена потреба у само ідентифікації та самоствердженні Митця, спробі подолання ним усталених етнічно сформованих i закарбованих у тло генетичної сутності соціальних стереотипів, стають основним мотивом його творчості, його рефлексії, кристалізованої у структурі національної пам'яті історії, культури, мистецтва. Глибоко особистісні поступи Майстра, сповідувана ним концепція буття, формують етнічно пізнаване ядро будь-якого національно-культурного надбання, виокремлюючи творчу постать як суб'єкта культури, що формує відмінний, якісно новий рівень мистецького i соціокультурного діалогу, в якому людина проносить потужний мотив пам'яті, вмонтований у ііі індивідуальність, неповторність і самобутність. На таких, зрощених хронотопом становлення особистості моделях, відбувається осмислення самобутності Художника, усвідомлення закономірності творчих процесів у сфері комунікативних зрізів, де яких особистість постає як неповторний і незламний вектор розвитку культури, у всіх іiї проявах: мові, мистецтві, комунікації.

Мета роботи. Дослідження обумовлене висвітленням одного 3 періодів творчої біографії Д. М. Гнатюка, який пов'язаний з формуванням життєвих векторів особистості під час навчання у Київській консерваторії. Методологія дослідження полягає в застосуванні історичного, біографічного та культурологічного методів 3 метою раціонального і послідовного 
висвітлення біографічних етапів Д. Гнатюка та формування його виконавського професіоналізму в координатах української соціокультурної динаміки другої половини $40-\mathrm{x}-$ початку 50 -х років XX століття.

Наукова новизна роботи полягає у виокремленні одного з етапів творчої біографії Д. Гнатюка в окрему сторінку вітчизняної культурномистецької спадщини, що дає можливість вивчення не тільки локальноособистісного простору митця, а й стереотипів загальної динаміки освіти, мистецтва, культури, стратегії їх становлення, розвитку та популяризації.

Виклад основного матеріалу. Творчий доробок Митця, його спадщина визначається не тільки силою таланту, індивідуальністю світосприйняття та його рефлексією, а й синтезом генетичного досвіду, узагальненням етнічнодетермінованих надбань у площині історії, науки, мистецтва. Творчість майстра - це те осереддя, яке нанизує на своє вістря попередні досягнення митців, узагальнюючи їх власними звершеннями і формуючи координати майбутніх поступів у сфері науки, культури, мистецтва.

1946 року, після перемоги на обласному огляді художньої самодіяльності Д. М. Гнатюк вступає до Київської державної консерваторії iм. П. І. Чайковського і здобуває статус студента вокального факультету. Несамовита жага студента до мистецтва, до пізнання таїнства оперного жанру, акторської практики стимулює його до натхненної роботи над самовдосконаленням, до вивчення комплексу фахових дисциплін, усестороннього розвитку та ерудиції. Згадуючи перші кроки у світ професійного академічного мистецтва, Дмитро Михайлович говорив: «Консерваторія - то мистецька мати для молодих. Як могутньо височіє народжене щасливим життям на квітучій землі дороге всім народамбратам наше життєствердне музичне мистецтво над безбарвністю, сірятиною отієї модерняцької тарабарщини буржуазного світу, що подібна до «музики» тієї гарби, з якої на вибоїнах ось-ось поспадають колеса. Перевіряймо ідейно-художню цінність кожного свого твору, своєї праці високими критеріями свого рідного народу. I зроблене, досягнуте нами стане бажаним та дорогим усім народам-братам як яскравий і повноцінний внесок у скарбницю надбань всієї нашої соціалістичної культури» [2].

Під керівництвом видатного оперного виконавця, провідного актора національної опери, народного артиста СРCP I. С. Паторжинського, Дмитро Михайлович опановує техніку професійно-академічного сольного співу з пріоритетом розвитку навиків оперного виконавця. Щоденна робота у класі над опануванням виконавської техніки продовжувалася систематичним закріпленням навиків під час проведення творчих зустрічей, звітних концертах класу, музичних вечорів. Методичні та 
практичні впровадження педагога давали можливість Дмитру Михайловичу сформувати уявлення про традиції як вітчизняної так і зарубіжної вокальної школи, опанувати стилістичні основи італійського бельканто та широкий проникливий баритоновий репертуар російської й української оперної традиції, поглибити здобутки фахових знань з сольфеджіо, гармонії, камерного співу, майстерності актора, сценічного руху, оперного класу.

Оволодівши базовими знаннями майстерності актора, сценічного руху, оперного класу, Д. М. Гнатюк вже на другому році навчання починає заняття в Оперній студії під контролем досвідчених музичних майстрів, таких як: В. Пірадов, М. Гончаров, Г. Таранов, О. Сандлер, А. Колодуб, Ю. Лишанський, В. Чемезов, Р. Ельвова, Н. Скоробагатько, В. Тараканов [5]. Репертуарний потенціал студії знаходився в стадії перманентних пошуків та апробацій, що потенційно впливало не тільки на загальну фахову підготовку студентів, а й на координати національного оперного жанру. Тотальний деформуючий вплив на динаміку становлення та розвитку підрозділу мала відсутність кадрового виконавського потенціалу та проблеми в його загальній структурній організації. Лише 1946 року, після 10-ти років занепаду, студія відновила свою роботу, отримавши статус оперного театру II категорії. Відбувався поступовий анастазис оперного виконавства в київській консерваторії: репертуарна площина студії формувалася на оперній спадщині П. І. Чайковського, М. В. Лисенка, В. А. Моцарта, велися активні роботи по напрацюванню методичного матеріалу, формувалася технічна основа елементів сценічного оформлення, світлового та реквізиторського матеріалу, декорацій та іншого необхідного театрального інвентарю.

Із рецензій Б. Зав’ялова стає відомо, що у 1948 році ведеться активна робота по підготовці опери П. І. Чайковського «Черевички», сцени з якої студенти вивчають і практично закріплюють під час занять 3 дисципліни «Оперний клас» [4]. Однією 3 ролей, яку виконував Д. Гнатюк була партія Свєтлєйшого. Під пильним наглядом викладача I. C. Паторжинського та провідного соліста оперного театру В. Борищенка, Д. Гнатюк розгерметизовує нові, недосяжні йому раніше сторони академічно-професійного мистецтва формуючи системні уявлення щодо вміння актора інтерпретувати сценічний образ, стилістично трансформувати лексику артиста та механізми раціонального навантаження вокально-голосового апарату, осмислювати жанрові та стильові концепції вистави. 
Маючи потужний голосовий апарат, Дмитро Михайлович швидко формує провідний баритоновий репертуар студії і виконує 1948 року партію Онєгіна 3 опери П. І. Чайковського «Евгеній Онєгін». У рецензії вистави Л. Карелін зазначає: «Студент третього курсу консерваторії Д. Гнатюк показав цілком професіональні вокальні і сценічні дані. В опері партія Онєгіна - одна з найскладніших. Дуже важко, не маючи достатнього досвіду, показати внутрішню спустошеність Онєгіна, відсутність у нього ідеалів. Д. Гнатюк глибоко розуміючи музичний образ, виразно відтворює на сцені пушкінського героя. Студент має для цього всі дані - красивий сильний голос великого діапазону, яскравість тембру, вдячну сценічну зовнішність» [6].

Наступним акторським втіленням на сцені Оперної студії стала роль Графа - 3 опери В. А. Моцарта «Весілля Фігаро». Аналізуючи рецензії Ю. О. Станішевського та Т. Суярко, можна беззаперечно стверджувати, що Д. Гнатюк активно працює над стилістичною координацією жанрової сутності опери. Відсутність сценічної практики і акторських навиків, стали запорукою численних непорозумінь та психологічної невпевненості актора. Згадуючи участь у постановці «Весілля Фігаро», Д. Гнатюк акцентує увагу на значних проблемах у опанування стильовими особливостями та жанровими механізмами вистави: «Перший мій виступ в оперному спектаклі був невдалим $\mathrm{i}$ для мене дуже повчальним. Коли згадую про нього, то й зараз проймає дрож i наче звучить грізний голос диригента Тольби: «Тут не поважають мистецтва!». Це він кинув на мою адресу під час студійної вистави «Весілля Фігаро» В. Моцарта, в якій я дебютував у партії графа Альмавіви. Вокальна партія була для мене надзвичайно складною, бо вимагала тонкого відчуття моцартівського стилю і граничної точності інтонування. Уважно і напружено я стежив за диригентською паличкою та помилився і забув виконати режисерські мізансцени. Тольба був страшенно обурений і вважав це злочином пам'яті Моцарта. То був для мене дуже серйозний урок» - згадує митець [10, с. 15]. Але акторпочатківець формував для себе ті координати сценічно-виконавської техніки, які мали для нього практично-необхідне значення у механізмах психологічного моделювання ролі, сценічного перевтілення та миттєвого адаптування до театрального простору [12].

Формування Д. М. Гнатюка як майстра оперного жанру доповнювалося, окрім навчання у Оперній студії, ще й відвідування спектаклів, а головне - репетицій оперного театру. Він мав можливість спостерігати за роботою видатних оперних режисерів Д. Смолича i В. Манзія та диригентів В. Тольби і К. Симеонова. 
Першою роллю на професійній сцені Д. М. Гнатюка стала партія Миколи 3 твору І. Котляревського «Наталка Полтавка». Театральна ідентифікація Дмитра Михайловича відбулася на сцені драматичного Державного академічного українського театру ім. І. Я. Франка. 3 ініціативи режисера-постановника А. Бучми, Д. М. Гнатюка було запрошено на виконання ролі Миколи. Дмитро Михайлович, у спогадах про зустріч 3 режисером згадає: «3 першої зустрічі з Бучмою, стало зрозумілим: до цих пір я про роль і поняття не мав. Веселун, український Фігаро - таким грали Миколу. I ось Амвросій Максиміліанович виділив у тексті лише одну фразу: «Піду по світу, пристану до козаків, може, у них знайду свою долю». I запропонував: «Подумайте про ці слова!». Козаки - це ж символ свободи селян епохи кріпацтва. Це ж морок царського гніту опротестовує своїм незгасними норовом мій Микола. Він не балагур, а борець. Розум і оптимізм народу стоять за ним. Дякуючи Амвросію Максиміліановичу всю роботу над роллю я розпочав з початку» [1].

Напрацьований попередньо потенціал у Чернівецькому музичнодраматичному театрі імені О. Кобилянської під керівництвом В. Василька щодо сценічного втілення образу Миколи та практика акторської майстерності в драматичному театрі під керівництвом А. М. Бучми, дали можливість оцінити потенціал молодого актора й на сцені Оперної студії. I. C. Паторжинський віднайшов преференції молодого виконавця і допоміг реалізувати Дмитру Михайловичу його детерміновані національним походженням сценічні образи Миколи. Результат вистави ілюстрував великий успіх молодого актора на сцені. Дмитро Михайлович відчував абсолютну паритетність 3 досвідченими виконавцями головних ролей опери, що стимулювало його до нових творчих пошуків та звершень. Видатний баритон М. Гришко дав таку характеристику його оперно-виконавській практиці в студії: «Чув, чув про твого Миколу, юначе! Може, скоро і мене будеш у цій партії заміняти» - зазначає Ю. Станішевський [10, с. 40].

1949 року, будучи студентом 4 курсу консерваторії Дмитро Михайлович осягає непорушні виміри оперної сцени київського театру опери та балету, виконуючи партію Миколи 3 опери М. Лисенка «Наталка Полтавка». Практика оперного співу поступово набирала своїх мистецьких обертів, і залучення Д. М. Гнатюка до вистав театру значно зросло, що позначилося на техніці його акторської майстерності та володінні засобами оперно-сценічної комунікації.

Наступним етапом формування Дмитра Михайловича як оперного виконавця була участь у виставі С. Рахманінова «Алєко». Молодий, сповнений оптимізму і внутрішніх переконань образ Алєко у авторській 
інтерпретації Дмитра Михайловича дещо нівелював образ, концептуально закладений драматургією композитора. Як зазначає Ю. Станішевський, переконливий вокальний потенціал виконавця повністю відповідав моделі драматичного героя С. Рахманінова. Але зрілий, екзистенційно сумний, 3 надривом внутрішнього світу героя сценічний образ, відтворений Д. М. Гнатюком на сцені Оперної студії, переконував глядача у наступному - роль не культивована внутрішніми переживаннями актора, не носить драматичного смислового навантаження, що надає їй виконавської поверховості і неповноти розкриття драматургії вистави [10, с. 42].

Молодий актор продовжує формувати координати власного мистецького простору, про що свідчить його участь у постановці вистави Ю. Мейтуса «Молода гвардія», в якій артист 3 успіхом виконав партію Євгена Стаховича [10, с. 43]. Детермінована суспільною потребою ідентифікації соціальної паритетності, висвітлення внутрішнього страждання та болю особистості в часи протистояння фашизму, опера увійшла до золотого фонду вітчизняного оперного простору. Під чітким керівництвом диригента студії В. Тольби та режисера О. Завіни, вистава набула широкого резонансу i стала предметом численних творчих дискусій та обговорень. Як зазначає I. Драч, сутнісною основою оперної творчості Ю. Мейтуса $\epsilon$ документальність, як чітка ознака реалістичності, відкритості та щирості почуттів героїв [3, с. 175]. Темперамент солістів студії, консолідоване артистами оркестру та хору відчуття основної ідеї твору, їх віра у знамена соціального відродження та відновлення ідеалів, що були втрачені, сформували потужний мистецький континуум, який активно окреслив оперну драматургію в контексті виконавської інтерпретації [7, с. 196].

Разом 3 I. Паторжинським та О. Завіною проходить активна робота по втіленні режисерських завдань зі студентами кафедри сольного співу, які займають активну позицію у роботі молодого театру. Активна практика виконавців-початківців на сцені оперної студії доповнювалася пропозиціями автора опери, який разом 3 диригентом та режисером працював над поставкою вистави. Динаміка проведення репетицій та перманентність творчих пошуків відкривали нові зрізі оперного жанру для молодих акторів. Вони переймали традиції критичного реалізму та методів його сценічного втілення, здобували досвід акторської майстерності, яка формувалася в результаті виконавської інтерпретації, формували власну концепцію естетичної ідентифікації своїх героїв на сцені оперної студії. Приймаючи участь у постановці «Молодої гвардії», Д. Гнатюк отримав можливість спостерігати систему побудови драматургії конфлікту, отримав можливість 
практично закріпити методи сценічного втілення наскрізного розвитку вистави, відчути закономірності синтетичних моделей академічного музичного матеріалу зі зразками народнопісенних виконавських форм.

Д. Гнатюк, окрилений ідеєю патріотизму та прагненням генераційного протистояння ідеологічному мороку, розсікаючи тло музичної драматургії твору впевнено вступив у діалог зі складною, реалістично-документальною оперою століття. Відверта, вишукана графіка образних ліній актора яка динамічно пульсувала у його акторській інтенції, презентувала молодого артиста у новому виконавському кредо - актор елемент, який акумулює драматургію твору, несе і впроваджує у дійсність головну думку, ідею, сценічне завдання, і тому сценічна майстерність - це достовірне переживання драматургії ролі, це повне занурення у вимір психологічного та смислового навантаження образу, i, спекулюючи даними поняттями, відблиск професійного акторського надбання поступово меркне і зникає у плинності часу.

Напрацьований досвід роботи Дмитра Михайловича над сценічним втіленням образу Свгена Стаховича на сцені Оперної студії, детермінує його участь у проведенні вистави вже у Київському театрі опери та балету.

Окрім потужної роботи Дмитра Гнатюка в різних жанрових координатах студії, театру, хору, він активно залучається до культивування національно-виконавських традицій $\mathrm{i}$ на рівні державної урядової програми. У особистих архівах Д. Гнатюка зберігається наказ №214 комітету радіофікації та радіомовлення при раді міністрів УРСР від 6 листопада 1948 року про створення чоловічого вокального квартету для систематичної роботи перед мікрофоном [8]. Головним завданням квартету була популяризація і пропаганда радянської пісні, народної творчості та продукування вітчизняної класики. Дмитро Гнатюк був включений до чоловічого ансамблю разом з такими виконавцями як: Ф. Максименко (Iтенор), В. Тітух (II-тенор), Д. Гнатюк (баритон), Є. Червонюк (бас) під керівництвом Г. Л. Жуковського. Цього ж року, Дмитро Михайлович влаштовується на посаду соліста хору до Державного Українського Народного хору під керівництвом Г. Верьовки і вже з 1950 року, прізвище Д. Гнатюка буде зазначено в історії київського театру опери та балету [11]. 1951 року Д. Гнатюк закінчує консерваторію зі спеціальності «Сольний спів» і отримав кваліфікацію оперного та концертного виконавця.

Період, пов'язаний з навчанням Д. Гнатюка у київській консерваторії пройде під гаслом формування практичних знань, умінь і навичок в просторі оперного та камерного виконавства. Система підготовки професійних академічних виконавців стимулювала Д. Гнатюка до засвоєння 
всього комплексу знань 3 метою повної відповідності вимогам оперного актора. За період навчання Д. Гнатюка, на сцені оперної студії буде здійснено постановку таких оперних вистав як: «Євгеній Онєгін» та «Черевички» П. І. Чайковського, «Майська ніч» та «Русалка» М. РимськогоКорсакова, «Весілля Фігаро» В. А. Моцарта, «Молода гвардія Ю. Мейтуса», «Наталка полтавка» М. В. Лисенка, С. Рахманінова «Алєко».

Висновок. Формування творчої особистості $€$ надзвичайно важливим і складним етапом, що вимагає чіткої координації діяльності, прикладення великих зусиль і часу. Динаміка накопичення потенційного досвіду, в площині складної структурної сітки мистецького середовища, обумовлює дотримання раціональної послідовності в опануванні виконавськими механізмами як акторської майстерності так і вокальносценічного професіоналізму. Для Д. Гнатюка, навчання в консерваторії i особливо участь у роботі оперної студії, зіграло важливу роль. Період творчого становлення актора віддзеркалює динаміку якісних змін в системі психологічного розуміння ним сутності театрального виконавства, формує i чітко координує напрямок щодо набуття виконавського досвіду, фахової компетентності та жанрової обізнаності.

Незважаючи на складні соціо-політичні та ідеологічні вектори повоєнних років, формування творчих стереотипів Д. Гнатюка кристалізується поступами значних мистецьких зрушень ХХ століття, що відображено консолідованою системою розробки сценічної концепції музичної драматургії, чітко сформованими механізми формування і реалізації сценічного задуму та його жанрових модифікацій, розширенням тематики образної системи, втіленням нових форм сценічної практики, елементів оформлення кабінету, реквізиту. Зміна соціальних стандартів зумовила кристалізацію у виставах нової образної системи 3 культивуванням актуальних, детермінованих часовими координатами питань.

Така концепція оперного відродження стимулювала до перманентної трансформації традиційних виконавських традицій оперного жанру та формування переконливих і логічно обумовлених образних рішень, культивування нового типу драматургічного конфлікту. Динаміка жанрової консолідації обумовлює новий тип оперної творчості, на авансцені якої фундаментально висвітлюється експериментальний театр в контексті режисерської та виконавської інтерпретації. Така проекція творчих пошуків та сценічних практик відкриває нові горизонти для ідентифікації Д. М. Гнатюка, стимулює його до естетичної трансформації, консолідує внутрішнє відчуття акторської сутності, заповнює та моделює системні уявлення щодо культурно-мистецької парадигми. 
1. Вирина Л. Отдаю голос//Советская культура. Москва. 1972. 9 декабря.

2. Гнатюк Д. М. Про нинішнє й прийдешнє//Літературна Украӥна. 1972. 29 вересня.

3. Драч I. Оперний світ Ю. Мейтуса//Науковий вісник Національної музично академії України імені П. І. Чайковського. Вип. 34: Юлій Сергійович Мейтус. Сторінки життя і творчості. Спогади. Статті. Листи. Матеріали (До 100-річчя від дня народження). Київ, 2006. С. 172-179.

4. Зав'ялов Б. Поліпшити виховання музичних кадрів//Радянське мистецтво. 1948. 23 червня.

5. Історична довідка оперної студї Київської державної ордена Леніна консерваторії ім. П. І. Чайковського//Архів НМАУ ім. П. І. Чайковського. Ф. № Р-810.

6. Карелін Л. Іспит на зрілість//Радянське мистеитво. 1948. № 3.

7. Мейтус Ю. С. Воспоминание о Вениамине Савельевиче Тольбе//Науковий вісник Національної музичної академії Украӥни імені П. І. Чайковського. Вип. 34: Юлій Сергійович Мейтус. Сторінки життя і творчості. Спогади. Статті. Листи. Матеріали (До 100-ліття від дня народження). Київ, 2006. С. 195-199.

8. Наказ № 214 комітету радіофікаиії та радіомовлення при раді міністрів УРСР. Про створення чоловічого вокального квартету для систематичної роботи перед мікрофоном. Київ, від блистопада 1948 р.//Особистий архів Д. М. Гнатюка. Зберігається в родині Гнатюків. 1 арк.

9. Саєнко М. Дорога до щастя//Радянська Буковина. 1946. 29 вересня.

10. Станішевський Ю. О. Дмитро Гнатюк. Київ: Музична Украӥна, 1991. 167 с.

11. Стефанович М. Київський державний ордена Леніна академічний театр опери та балету УРСР імені Т. Г. Шевченка. Історичний нарис. Київ: Держвид.образ. мистецтво і муз. літ. УРСР, 1960. 208 с.

12. Суярко Т. Двадиять київських весен//Особистий архів Д. М. Гнатюка. Зберігається в родині Гнатюків. 32 арк. Рукопис.

\section{References}

1. Virina, L. (1972). Otdayu golos [I give voice]. Moscow, Soviet culture.

2. Virina, L. (1972). Otdayu golos [I give voice]. Moscow, Soviet culture.

3. Gnatyuk D. (1972). Pro nynishnye y pryydeshnye [About current and future]. Kyiv, Literary Ukraine.

4. Drach, I. (2006). Drach I. Opernyy svit Y. Meytusa [The operatic world of Y. Mateus]. Kyiv, P. 172-179.

5. Zavialov, B. (1948). Polipshyty vykhovannya muzychnykh kadriv [Improve education of musical cadres]. Kyiv, Soviet art.

6. Istorychna dovidka opernoyi studiyi Kyyivskoyi derzhavnoyi ordena Lenina konservatoriyi im. P. I. Chaykovskoho (1983). [Historical reference of the opera studio of the Kyiv State Orders of Lenin to the Conservatoire P. I. Tchaikovsky].

7. Karelin, L. (1948). Ispyt na zrilist [Examination on maturity]. Kyiv, Soviet art.

8. Meitus, Y. (2006). Vospominaniye o Veniamine Savel'yeviche Tol'be [Recollection of Benjamin Savelievich Tolbe]. Kyiv, P. 195-199.

9. Order No. 214 (1948). Nakaz № 214 komitetu radiofikatsiyi ta radiomovlennya pry radi ministriv URSR [of the Radio and Radio Committee of the Council of Ministers of the USSR]. Kyiv.

10. Sayenko, M. (1946). Doroha do shchastya [Road to happiness]. Soviet Bukovina.

11. Stanishevsky, Y. (1991). Dmytro Hnatyuk [Dmytro Hnatyuk]. Kyiv, Musical Ukraine. 
12. Stefanovich, M. (1960). Kyyivskyy derzhavnyy ordena Lenina akademichnyy teatr opery ta baletu [The Kyiv State Orders of Lenin Academic Opera and Ballet Theater]. Kyiv.

13. Suyarko T. Dvadtsyat kyyivskykh vesen. [Twenty Kiev spring]. Kyiv, P. 32. 